\title{
VOLUNTEERING IN CROSS-NATIONAL PERSPECTIVE: INITIAL COMPARISONS
}

\author{
Helmut K. ANHEIER* AND LeSTER M. SALAMON**
}

INTRODUCTION

Volunteering has not only become an important issue in the United States; it is also receiving much more attention in many other countries. In many ways, volunteering enjoys greater political and cultural recognition today than it did in past decades. As frequently happens, however, greater awareness seems related to the extent to which an issue is seen as problematic, or as something beneficial that no longer can be taken for granted. The environment, the family, community, and social security are cases in point, and, as we suggest in this article, so is volunteering, particularly when seen from a cross-national perspective.

In the past, volunteering was often viewed in isolation from the wider social and cultural context. However, volunteering is much more than simply the giving of time for some particular purpose. In fact, as a cultural and economic phenomenon, volunteering is part of the way societies are organized, how they allocate social responsibilities, and how much engagement and participation they expect from citizens. As discussed below, the role of the state and the nature of state-society relations are important aspects that shape the role of volunteering cross-nationally. Not surprisingly, the fortunes of volunteering as a social institution are, and have been, changing over time, and vary by cultural and political context. The purpose of this article is to shed some initial light on volunteering in different parts of the world by exploring the conceptions and patterns of voluntary action cross-nationally.

In some European countries, such as Sweden and Germany, volunteers were, until recently, regarded as amateurish "do-gooders," as relics of the past to be replaced by paid professional staff capable of performing tasks more effectively and efficiently. ${ }^{1}$ If there was a role for volunteers in the modern welfare state, it was a marginal one at best, that is, to supplement professionally planned and delivered services. What is more, other countries saw no need for volunteers at all. The Japanese government, for example, drew up contingency

Copyright (C) 1999 by Helmut K. Anheier and Lester M. Salamon

This article is also available at http://www.law.duke.edu/journals/62LCPAnheier.

* Director, Center for Civil Society, London School of Economics.

** Director, Center for Civil Studies, Johns Hopkins University. 1999).

1. PerspeKtiven Gesellschaftlichen Zusammenhalts 201-09 (Ernst Kistler et al. eds., 
plans for responding to natural disasters in which volunteers had no role. ${ }^{2}$ Dealing with disaster was seen as the primary and exclusive domain of the state administration. ${ }^{3}$ When the Kobe earthquake hit in 1995, conflicts soon erupted between a government too slow to respond, and the thousands of Japanese citizens who had spontaneously decided to volunteer their services to help ease the critical situation. ${ }^{4}$

In the former socialist countries of Central and Eastern Europe, the very concept of volunteering became obsolete, contaminated by decades of state and party requirements to contribute time and efforts freely for some common social, cultural, or political cause. After 1989, countries in the region set out to modernize their social service and health care systems. In doing so, these governments paid very little attention to the role and potential contributions volunteers could make to improving state-run institutions, many of which were under-funded and short-staffed. ${ }^{5}$ Finally, in developing countries, a great diversity of indigenous forms of volunteering coexists with Western ways. For example, in Nigeria and Ghana, like in many African countries, village associations of volunteers can be found in nearly every rural and urban community. ${ }^{6}$ Rooted in the local culture, they provide communal services and assistance in times of need. These associations coexist with local chapters of organizations like the Young Women's Christian Association or the Boy Scouts, modeled after their American or British counterparts. ${ }^{7}$ At the same time, however, like many countries in the north, most developing countries, until recently, regarded volunteering as a matter of low priority, and very few instituted policies and programs to encourage volunteering. ${ }^{8}$

Fortunately, cross-national attitudes toward voluntarism have radically changed in recent times. On November 20, 1997, the fifty-second General Assembly of the United Nations declared the year 2001 as the Year of the Volunteer,' with the Japanese government as one of its main sponsors along with 122 other countries. December 5 was designated International Volunteer Day, now celebrated every year by more than 100 countries worldwide. ${ }^{10}$ The European Union is championing the case of voluntary work and greater participation at

2. See generally Masa Deguchi, Japan, in ThE NONPROFIT SECTOR AT THE CROSSROAds? AN INTERNATIONAL POLICY ANALYSIS (Helmut K. Anheier \& Jeremy Kendall eds., forthcoming 2000).

3. See id.

4. See id.

5. Eva Kuti, The Nonprofit Sector in Hungary, in 2 THE JOHNS HoPKINS NONPROFIT SERIES 1, 126-33 (Lester M. Salamon \& Helmut K. Anheier eds., 1996).

6. See Helmut K. Anheier, Indigenous Voluntary Associations, Nonprofits, and Development in Africa, in THE NonPRofit SECTOR: A ReSEARCH HANDBOoK 416, 427-28 (Walter Powell ed., 1987).

7. See id. at $420-21$.

8. See Helmut K. Anheier \& Lester M. Salamon, The Nonprofit Sector in the Developing World, in THE JOHns Hopkins NONPROFIT SERIEs 348, 348-49 (Helmut K. Anheier \& Lester M. Salamon eds., 1998).

9. See United Nations, International Year of the Volunteer 2001, Background Note (visited Jan. 22, 2000) <http://www.iyv2001.org/sitemap/index.htm> [hereinafter International Year].

10. See id. II 9. 
the community level. ${ }^{11}$ Of course, few countries can match the public recognition that was given to volunteering by the White House Conference on Philanthropy and Voluntarism hosted by President Clinton in Washington, D.C., on October 26, 1999.

National governments across the globe are beginning to pay more attention to volunteering and seek to support and encourage it. For example, in the aftermath of the 1995 Kobe earthquake, Japan is considering ways to encourage volunteering. ${ }^{12}$ In 1999, the Labour government in Britain launched the Active Community Unit attached to the Prime Minister's Office in an effort to increase the level of volunteering and local community participation in British towns and villages. ${ }^{13}$ Similarly, other European countries like Italy or France have established volunteer centers to inform citizens about volunteer opportunities, and the Netherlands and Germany set up local coordinating agencies to match volunteers to organizations that might need them. ${ }^{14}$

At the dawn of the twenty-first century, volunteering also is transcending national boundaries and is becoming an international phenomenon. Missionary societies, religious orders, and other types of religious organizations have operated internationally for many centuries, particularly so since the early 1900s, carried by the evangelical revival movement that swept the United States and Europe at that time. The birth of the modern volunteer movement outside the realm of the state (for example, volunteer armies and work corps), church (for example, laymen) and community (for example, mutual assistance and caring) is closely associated with the creation of the Red Cross in 1864. For more than 100 years, the Red Cross and Red Crescent societies have pioneered volunteering and organized volunteers for humanitarian assistance, to alleviate suffering and poverty. In 1998, more than 100 million people volunteered for the Red Cross/Red Crescent movement worldwide. ${ }^{15}$

Another international volunteer organization emerged in 1971 with the United Nations Volunteer program. In addition, government-organized programs such as the Peace Corps, Canadian University Service Overseas, Britain's Voluntary Service Overseas, and similar programs in other countries began to operate, and offered opportunities for people to volunteer in developing nations. More generally, the internationalization of voluntary efforts developed alongside the expansion of non-governmental organizations active in development and relief efforts in many countries of Africa, Latin America, and Asia. While some volunteer organizations like Amnesty International, Médicins Sans

11. See COMmission of the European COMMUnities, Promoting the Role of Voluntary ORganizations IN Europe 2-3 (Office for Official Publications of the European Communities 1997) [hereinafter COMMISSION OF EUROPEAN COMMUNITIES].

12. See Deguchi, supra note 2. On the new non-profit law in Japan, see also Economic Planning Agency of Japan, Outline of the Law to Promote Specified Nonprofit Activities (visited May 4, 2000) $<$ http://www.epa.go.jp/98/c/19980319c-npo-e.html>.

13. See Home Office, Active Community Unit (visited May 4, 2000) <http://www.homeoffice.gov. uk/cpg/acu2.htm>.

14. See Perspektiven Gesellschaftlichen Zusammenhalts, supra note 1, at 201-10.

15. IFRC, Volunteering Review Project, Trend Report 20004 (Jan. 2000) (draft). 
Frontières, and Greenpeace may have started as national organizations, they have become increasingly international in their recruitment and operations.

Like so many other parts of economy and society, volunteering has entered the age of globalization. The International Association for Volunteer Efforts has member organizations in more than 100 countries, and the Internet has facilitated new initiatives by matching volunteers to organizations; examples include the International Medical Volunteers Association, Global Volunteers, One World One Volunteers, and Virtual Volunteering. ${ }^{16}$ At the international level, the role of volunteers also has become politically more vocal and visible, sometimes influencing "official politics." For example, the 1992 Earth Summit in Rio de Janeiro, the 1995 World Summit on Social Development in Copenhagen, the 1997 World Women's Conference in Beijing, and the 1999 meeting of the World Trade Organization in Seattle would most likely have achieved different outcomes had non-governmental organizations and their many volunteers not been present.

Yet, while volunteering is emerging as an international phenomenon, there is at the same time a growing awareness that the meaning and patterns of volunteering are changing, particularly at the local level. Individualization and secularization are redefining volunteering. Today, volunteering is less linked to religion, notions like "service to the nation," and traditional expectations. ${ }^{17}$ Instead, it is tied more to specific needs, self-interest, and greater individual choice. In response, governments and nonprofit organizations alike are attempting to create new institutional structures to encourage volunteering, and to make it more appealing to the more self-interested members of modern societies. One example is the voluntary social year in Germany, where youths can volunteer in social services programs linked to skill training and professional qualifications. ${ }^{18}$ Another example is the Active Community Unit of New Labour in Britain that seeks to encourage participation and caring behavior at local levels by drawing in socially excluded parts of the population. ${ }^{19}$

International organizations, too, try to foster greater recognition and support for volunteers. The Final Declaration of the 1995 U.N. World Summit on Social Development in Copenhagen called for the promotion of volunteering and requested governments to make appropriate resources available to support such work. ${ }^{20}$ Other international institutions see a strong link between individual participation in public life, volunteering, and democracy. ${ }^{21}$ In this sense, governments are resounding the Tocquevillian notion that volunteers are part

16. See United Nations, Other Volunteer Organizations (visited Jan. 21, 2000) <http://www.unv.org/ unvols/volhelp.htm>.

17. See infra text accompanying notes 51-52.

18. See PERSPEKTIVEN GESELLSCHAFTLICHEN ZUSAMMENHALTS, supra note 1, at 264-66.

19. See Home Office, supra note 13.

20. United Nations, Final Declaration and Programme for Action, World Summit for Social Development, Copenhagen (visited Jan. 22, 2000) < http://www.un.org/esa/socdev/geneva2000/docs/ summit.pdf>.

21. See COMmission of European COMmunities, supra note 11, at 3-4. 
of the social glue that holds modern societies together, counteracting what are seen as the divisive tendencies of increased individualism and greater materialism. ${ }^{22}$

The "social glue" theory is pronounced in countries that have historically high levels of volunteering. However, this commitment to civic life can no longer be taken for granted. In Britain, France, and Germany, for example, levels of volunteering have stagnated in recent years and the governments have sought to respond. For some international organizations, such shifts had disastrous consequences. The International Federation of Red Cross/Red Crescent Societies reported a drop in volunteers from 250 million in the late 1980 s to little more than 100 million in $1998 .^{23}$ Even though this decrease is in part the result of the disintegration of former Soviet-type Red Cross societies in Central and Eastern Europe, the decline in volunteering for organizations like the Red Cross also is pronounced among the developed market economies of the European Union. Consequently, the Federation is reconsidering the role of volunteers and is searching for ways to upgrade their status in national Red Cross/Red Crescent societies. We can assume that changes in family structures and values have caused significant shifts in the supply, type, and motivation of volunteers.

Equally as important, many countries, particularly in Europe, struggle with persistent unemployment, and calls for a redefinition of traditional forms of work have become politically more acceptable. Some authors like Ulrich Beck and Jeremy Rifkin suggest elevating voluntary work to a status equal to paid work, and encourage the establishment of some form of social credit system for those performing communal tasks of various kinds. ${ }^{24}$ Under this system, volunteers could earn "social dollars" that, alongside their monetary contribution to social security system, would count toward health, educational, or retirement benefits. Irrespective of the merits of Beck's or Rifkin's approach, their thinking suggests that shifts are taking place in the role and potential of volunteering, and the role of paid work, service to the community, and social responsibilities. What is behind these developments? What factors draw attention to volunteers and volunteering?

22. See Alexis De TocQueville, Democracy in AMERICA (1990) (1835).

23. See IFRC \& RED CREsCEnt Societies, StRATEgy 2010: LEARNING FRom the Nineties AND OTHER SUPPORTING DOCUMENTS 141 (1999) [hereinafter IFRC, STRATEGY 2010]. We can speculate that one reason for the significant decline is the very organization of the Red Cross in the former Soviet Union, as a quasi-state organization. Membership in the Red Cross was encouraged, if not expected, by the Communist Party. With the collapse of the Soviet Union and the decline of the Communist Party, membership in the Red Cross dropped, and so has the level of volunteering. Moreover, we can assume that the number of volunteers active in the former Red Cross societies of Central and Eastern Europe was likely over-reported, as volunteering and membership were frequently treated as the same.

24. See generally Ulrich Beck, Schoene neue Arbeitswelt (1999); Jeremy RifKin, The END OF WORK (1993). 
II

\section{DEFINITIONS}

Not surprisingly, the notions of volunteering and volunteer vary across countries. The British and American concept of volunteering, the French voluntariat, the Italian voluntariato, the Swedish frivillig verksamhet, or the German Ehrenamt have different histories and carry different cultural and political connotations. ${ }^{25}$ In some countries, volunteering is intimately linked to the cultural identity and community as a substitute for nationhood. For example, in Israel, this connection is evident in the long experience of Diaspora and the collectivist voluntary spirit of Zionism. ${ }^{26}$ Similarly, in the United States, there is a strong link between volunteering as a cultural expectation and the realityand mythology - of the frontier society. ${ }^{27}$ This link is derived from America's individualistic "can-do" spirit.

In Australia or Britain, volunteering is closely related to the concept of a voluntary sector-a part of society seen as separate from both the business sector and the public sector of government and public administration. ${ }^{28}$ This notion of voluntarism has its roots in Lockean concepts of a self-organizing society outside the confines of the state. Civil society and voluntary action also resonate in the thinking of Scottish enlightenment philosophy, yet find their most eloquent expression in the work of Alexis de Tocqueville's Democracy in America. ${ }^{29}$ For de Tocqueville, voluntary action and voluntary association become cornerstones of a functioning democratic polity, in which a voluntary sector shields society from the tyranny of the majority. The link between voluntarism and democracy became deeply imprinted in American culture and the country's political self-image.

In other countries, however, the notion of volunteering is different and emphasizes communal service for the public good. The German term Ehrenamt, or "honorary office," comes closest to this tradition. ${ }^{30}$ In the nineteenth century, the modernization of public administration and the development of an efficient, professional civil service within an autocratic state under the reformer Lorenz von Stein allocated a specific role to voluntarism. Voluntary trusteeship of associations and foundations became the domain of the growing urban middle class. ${ }^{31}$ A vast network of associations and foundations emerged in the middle

25. See generally Defining the Nonprofit SECtor: A Crossnational ANAlysis (Lester M. Salamon \& Helmut K. Anheier eds., 1997).

26. See Benjamin Gidron, The Evolution of Israel's Third Sector: The Role of Predominant Ideology, 8(1) VOLUNTAS 11, 11-12, 15-17 (1997).

27. See generally Robert Bellah, HABits of THE HeART (1985).

28. See Jeremy Kendall \& Martin Knapp, The Nonprofit Sector in the United Kingdom, in DEFINING THE NONPROFIT SECTOR, supra note 25, at 272.

29. See generally DE TOCQUEVILLE, supra note 22.

30. See Eckart Pankoke, Zwischen Enthusiasmus und Dilletantismus: Gesellschaftlicher Wandel freien Engagements, in EHRE. FRANKFURT: SUHRKAMP 151 (Ludgera Vogt \& Arnold Zwingerle eds., 1994).

31. See Helmut K. Anheier \& Wolfgang Seibel, The Nonprofit Sector in Germany, in 9 THE JOHNS HOPKINS NONPROFIT SERIES (Lester M. Salamon \& Helmut K. Anheier eds., forthcoming 2000). 
and late nineteenth century, frequently involving paid staff, but operated and managed by volunteers. Unlike in the United States, the German notion of voluntarism as a system of honorary officers took place in a basically autocratic society where local and national democratic institutions remained underdeveloped. This trusteeship aspect of voluntarism began to be seen separately from other voluntary service activities such as caring for the poor, visiting the sick, or assisting at school. These latter activities were largely monopolized by the church until the industrialization period when emerging workers' movements took over some of these responsibilities.

In addition to different national traditions, voluntarism also is closely linked to the self-understanding of larger nonprofit organizations. The Red Cross considers voluntary service to be one of the seven fundamental principles of the Red Cross/Red Crescent movement along with humanity, impartiality, neutrality, independence, unity, and universality. ${ }^{32}$ It defines volunteers as "individuals who reach out beyond the confines of paid employment and normal responsibilities to contribute in different ways without expectation of profit or reward in the belief that their activities are beneficial to the community as well as satisfying to themselves." ${ }^{33}$

The United Nations offers a broader definition of volunteering as contributions that individuals make as nonprofit, non-wage, and non-career action for the well-being of their neighbors, and society at large. ${ }^{34}$ This definition is rather broad and includes mutual self-help and many forms of collective action. The United Nations sees volunteering primarily in its service function: "[V]oluntary service is called for more than ever before to tackle areas of priority concern in the social, economic, cultural, humanitarian and peacekeeping fields." ${ }^{35}$

How do the social sciences approach volunteering? In economics, volunteer work is a somewhat problematic concept because no market price exists to establish its value relative to changes in supply and demand. The U.N. System of National Accounts ("SNA") is a case in point. The SNA serves as the global methodological system on how to treat, measure, and report any type of economic activity. ${ }^{36}$ The system treats volunteer work as a nonmarket activity, ${ }^{37}$ just

32. IFRC and Red Crescent Societies, Framework for National Society Capacity Building, 07/98E 2000, Geneva, 1998, at 15, 22.

33. IFRC, Voluntering Review Project Trend Report 2000, at 9-10 (Geneva, Jan. 2000).

34. See United Nations, supra note 9, II 1.

35. Id. II 5.

36. See United Nations, System OF NAtional ACCOUnTs 1.1 (1993).

37. To calculate the imputed value of volunteer work, social scientists typically rely on data from population samples. The two key items are the number of volunteers in the sample, and the number of hours volunteered per volunteer. The proportionate share of volunteers is extrapolated to the whole adult population to obtain the total number of volunteers, which, in turn, is multiplied by the average number of hours volunteered. Finally, the total number of hours volunteered is then multiplied by a monetary value or shadow wage, which yields the imputed value of total volunteer time. This is the $\mathrm{r}$ eplacement value of volunteer time, but other approaches are also possible. See Edith Archambault et al., The Monetary Value of Volunteer Time: A Comparative Analysis of France, Germany and the United States (1998) (paper presented at the Review of Income and Wealth Conference, Lillehammer, Norway). 
like housework or leisure activities such as gardening. ${ }^{38}$ As a result, we have little systematic information on volunteering at the international level-virtually no statistical office collects data on volunteering as part of its regular, ongoing reporting.

These nonmarket activities are set apart from both mutual aid and forms of barter. Volunteering is work in the sense that it differs from leisure; also, it is voluntary and, therefore, distinct from paid work. The objective distinction between volunteer work and leisure is based on the third-party criterion, ${ }^{39}$ that is, the fact that some activities are nonmarketable because "it is impossible for one person to obtain another person to perform instead." ${ }^{40}$ For example, a sports club can either hire a paid coach or opt for asking someone to volunteer. Yet, if members choose to play some sport like tennis, they cannot pay a third party to play for them without losing the benefits of playing pleasure. Thus, membership participation is leisure; coaching is work. Likewise, attending an environmentalist rally is participation; organizing it without pay is volunteering.

From the subjective point of view, however, this distinction is not always clear. ${ }^{41}$ One source of confusion is tied to personal motivations and dispositions, especially when volunteering is mixed with advocacy functions: Can I pay somebody to visit the sick or the handicapped instead of me? Another source of confusion is the mix of membership and volunteering. For example, the Red Cross traditionally made little distinction between members and volunteers, as did many political parties and social movement organizations.

To minimize the effect of subjective interpretation, time-use tables and population surveys typically use some general description of volunteer work, and use examples to illustrate salient aspects of volunteering. In a French population survey carried out by Archambault, the questionnaire used a very specific definition of volunteer work to separate it from related aspects like membership, informal helping and behavior:

We will now ask you about volunteer work (or volunteering). By this, we mean unpaid work and time spent to offer a service to groups or nonprofit organizations, outside your family, your neighbors and your friends. For example:

(1) doing clerical work for an association or union

38. Recognizing that the SNA treatment may be somewhat simplistic, Emmanuel Chadeau and Claude Roy suggest breaking down economic activities into five categories:

(1) activities that are remunerated, reported, and typically included in official statistics;

(2) remunerated activities that are either legal or illegal but remain unreported;

(3) activities that are unpaid and intended for parties outside households;

(4) unpaid activities within households; and

(5) other activities.

See Emmanuel Chadeau \& Claude Roy, Relating Households Final Consumption to Household Activities: Subsidiarity or Complementary between Market and Non-market Production, in 32(4) REVIEW ON INCOME AND WEALTH SERIES 32 (1986).

39. See Oli Hawrylyshyn, Towards a Definition of Non-market Activities, in 23(1) REVIEW ON INCOME AND WEALTH SERIES 79, 88-89 (1977).

40. See United NAtions, supra note 36, at 6.16.

41. See Archambault et al., supra note 37. 
(2) running a youth organization

(3) coaching at sports clubs

(4) distributing food, clothes or helping with other relief activities

(5) volunteering as a fire-fighter or in emergency rescue programs

(6) cleaning open spaces or helping preserve wildlife, or

(7) working on committees or serving on boards. ${ }^{42}$

The distinction between voluntary and paid work is easier to make, and there is a clear difference in the status of volunteers versus employees. Of course, there are intermediate positions between completely unpaid work and work paid at labor market prices. For example, volunteers, in particular when serving on boards, are frequently reimbursed for related expenses, and some receive in-kind compensation. Similarly, larger nonprofit organizations in Germany provide benefits like health and accident insurance to volunteers, and some charities cover the pension payments for those working as volunteers overseas.

By contrast, some paid employees work for wages that are below market value. There are a variety of reasons for this. For one, employees may agree with the aim of the nonprofit organization and not demand a market rate. What is more, they may see volunteering as an investment for gaining skills and experience, which is typically the case for apprentices in many European countries. They may be required to accept lower wages because of labor market imperfections. Such is the case in countries with structural unemployment problems such as Spain or France, but also in virtually all developing countries where large portions of the population work in a "gray zone" of paid and unpaid labor. Certainly, these examples go beyond the narrower meaning of volunteering.

More generally, and especially when seen from a comparative, crossnational perspective, these examples illustrate the conceptual and methodological difficulties that conventional social and economic reporting systems have with the concept of volunteering, and suggest that we may have to consider different packages of paid and unpaid activities. For example, we arrive at a threedimensional array, as shown in Figure 1, that includes a time dimension (full time/part time); an economic dimension (paid activities/unpaid activities); and a social dimension (formal work environment/informal work environment).

Across different countries and population groups, we are likely to find different combinations among the three dimensions. What seems clear is that the combination "unpaid, formal, and part-time," which comes closest to a conventional understanding of volunteering, captures only one particular aspect that may be typical for industrial countries only. In contrast, the combination "informal, partly-paid, and part-time activities" might well be characteristic for

42. Edith Archambault, Questionnaire on Giving and Volunteering in France, Laboratoire d'Economie Sociale, Université de Paris I, Sorbonne, 1992, 1996. 
many developing countries. What is more, the supply of the combination "parttime, unpaid, and formal" in Europe or the United States may well become more precarious among some population groups because of the greater labor market participation of women and the elderly.

FIGURE 1

\section{COMBINATIONS OF WORK ACTIVITIES AND CHARACTERISTICS}

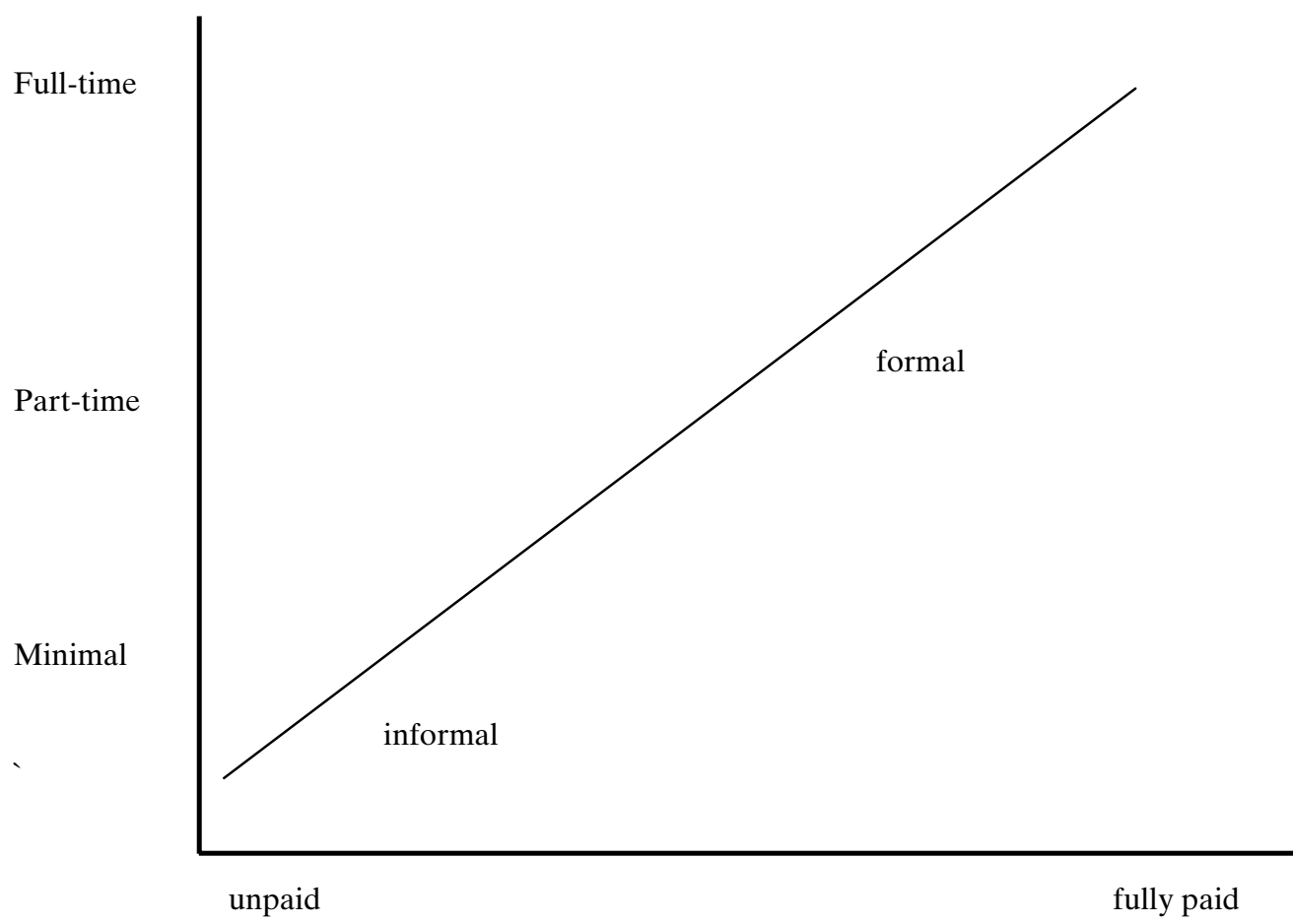

III

\section{VOLUNTEERING AND VOLUNTEERS ${ }^{43}$}

A 1995 study of volunteering in Europe found that twenty-seven percent of the adult population in the nine countries studied volunteered in the previous year-Belgium, Bulgaria, Denmark, Germany, Great Britain, Ireland, Netherlands, Slovakia, and Sweden. ${ }^{44}$ As Table 1 shows, the level of volunteering

43. Information on volunteering in most countries is still very limited. Even more scant is systematic, cross-national and long-term information that would allow comparisons based on a consistent methodology in terms of definitions, data collection, and sampling procedures. We will therefore have to draw from different surveys that vary in terms of the comparability, time frames, and topics covered.

44. Reported percentages are weighted averages based on the response distribution in each country. The study was coordinated by the National Centre for Volunteering in Britain and involved population surveys as part of a larger omnibus survey using a face-to-face questionnaire. Each national team used a standard set of questions with somewhat different sampling approaches, including quota sam- 
among the adult population in the nine countries varies significantly from a low of twelve percent in Slovakia to a high of thirty-eight percent in the Netherlands. ${ }^{45}$ Two-thirds of those reporting voluntary activity participated at least once a month, and five to ten hours each month was the most frequent category in terms of time given. ${ }^{46}$ The ten most frequent areas for volunteering are (1) sports and recreation (twenty-eight percent of all reporting to have volunteered during the last year); (2) social services (seventeen percent); (3) kindergarten and child care (thirteen percent); (4) community development (thirteen percent); (5) religion (thirteen percent); (6) health (eight percent); (7) culture and arts (seven percent); and (8) advocacy (seven percent). ${ }^{47}$

TABLE 1

Volunteers as Percentage of Adult Population IN EUROPE, BY SEX, 1995

\begin{tabular}{lccc}
\hline & $\begin{array}{c}\text { Percent of } \\
\text { Male } \\
\text { Population Reported } \\
\text { Voluntering }\end{array}$ & $\begin{array}{c}\text { Percent of } \\
\text { Female } \\
\text { Population Reported } \\
\text { Volunteering }\end{array}$ & $\begin{array}{c}\text { Percent of } \\
\text { Total } \\
\text { Population Reported } \\
\text { Volunteering }\end{array}$ \\
\hline Belgium & 27 & 35 & 32 \\
Bulgaria & 21 & 18 & 19 \\
Denmark & 29 & 27 & 28 \\
Germany & 18 & 17 & 18 \\
Great Britain & 31 & 36 & 34 \\
Ireland & 28 & 24 & 25 \\
Netherlands & 43 & 34 & 38 \\
Slovakia & 12 & 12 & 12 \\
Sweden & 38 & 32 & 36 \\
Total & 27 & 26 & 27 \\
\hline
\end{tabular}

Source: based on information reported in KATHERINE GASKIN \& JUSTIN DAVID SMITH, A NEW CIVIL EUROPE? A STUDY OF THE EXTENT AND ROLE OF VOLUNTEERING 28-29 (1997).

pling (Belgium, Republic of Ireland), random location (Netherlands), random location combined with quota controls (Britain), and multi-stage cluster sampling (Bulgaria, Denmark, Germany, Slovakia, and Sweden). Sample sizes are Belgium (870, French speaking population only), Bulgaria (1,073), Denmark $(1,843)$, Germany $(1,717)$, Great Britain $(1,054)$, Ireland $(1,404)$, Netherlands $(1,020)$, Slovakia $(1,015)$, and Sweden $(1,000)$. KATHERINe Gaskin \& Justin Davis SMITH, A New Civil Europe? A STUDY OF THE EXTENT AND ROLE OF VOLUNTEERING 115-17 (1997).

45. See infra Part IV (identifying some of the reasons why volunteering levels vary across different countries).

46. GASKIN \& SMITH, supra note 44 , at $28-31$.

47. See id. 
As shown in Table 1, the study found little systematic gender difference in overall levels of volunteering across countries, but reported higher levels of voluntary activities in the field of social services and health for women, and in the areas of sports, recreation, and culture for men. Moreover, men are more likely to be involved in committee work - thirty percent versus twenty-two percent for women - and less likely to be engaged in befriending and visiting activities-seventeen percent versus twenty-five percent. ${ }^{48}$ In most other areas of typical volunteers activity, such as office work, fund-raising, advocacy, teaching, and personal care, Gaskin and Smith found no major gender differences in the ten countries studied. ${ }^{49}$

Looking at social class, an earlier study of fourteen European countries showed a pronounced relationship between volunteering and social status. ${ }^{50}$ As Table 2 shows, volunteering is more frequent among higher socio-economic groups-professionals, academics and managers-than any other group. Thirty-four percent of respondents in the upper- and upper-middle-class stratum volunteered during the last year, as compared to twenty-one percent of lower-middle-class and sixteen percent of lower-class respondents. Not surprisingly, volunteering also varies with education, with highly educated people more likely to volunteer than less educated: Table 2 shows that thirty-seven percent of those with college degrees volunteered, compared to eighteen percent for those with less-than-high-school equivalent.

Gaskin and Smith and Barker analyzed why people decide for and against volunteering. In the Gaskin and Smith study, fifty-one percent volunteered because they enjoyed doing so; thirty-six percent did so as a means to make new friends; thirty-four percent enjoyed the satisfaction of seeing the results of their work; twenty-nine percent viewed it as a way to stay active; twenty-four percent volunteered for the experience gained; eighteen percent volunteered for the social recognition they gained in the community; and eighteen percent did it because volunteering helped them uphold their basic religious or political values (multiple answers). ${ }^{51}$ The reasons for not volunteering are no spare time left (forty-one percent), never having been asked (twenty-eight percent), and never thought about it (eighteen percent). ${ }^{52}$

48. See id.

49. See id. at 37.

50. See David G. Barker, Values and Volunteering, in 2 VOLUNTEERING IN EUROPE 10, 24 (Justin Davis Smith ed., 1993). Barker used the results of the 1990 European Value Surveys, which covered Belgium, Denmark, France, West Germany, Great Britain, Iceland, Ireland, Northern Ireland, Italy, Netherlands, Norway, Portugal, Spain and Sweden. The same questionnaire, which included questions on volunteering, was used in all participating countries. Sampling methods varied across countries, with most employing some form of quota sampling, cluster sampling, or some combination of both. Sample sizes ranged between 4,147 for Belgium and 702 for Iceland, with most countries between 1,000 and 1,500, which are standard sample size for population surveys in Europe. See id. at 12.

51. See GASKIN \& SMITH, supra note 44, at 50.

52. See id. at 54 . 
TABLE 2

VOLUNTEERING, SOCIAL CLASS AND EDUCATIONAL BACKGROUND IN EUROPE, 1990*

\begin{tabular}{lcccccccccc}
\hline & \multicolumn{3}{c}{ Socio-Economic Class } & \multicolumn{5}{c}{ Terminal Age of Education } \\
& $\begin{array}{c}\text { Upper/ } \\
\text { Upper } \\
\text { Middle }\end{array}$ & Middle & $\begin{array}{c}\text { Lower } \\
\text { Middle }\end{array}$ & Lower & 16 & 17 & 18 & 19 & 20 & $21+$ \\
\hline $\begin{array}{l}\text { Percent } \\
\text { Volunteering }\end{array}$ & 34 & 27 & 21 & 16 & 18 & 29 & 29 & 31 & 30 & 37 \\
$\begin{array}{l}\text { Not } \\
\text { Volunteering }\end{array}$ & 66 & 73 & 79 & 84 & 82 & 71 & 71 & 69 & 70 & 63 \\
Total & 100 & 100 & 100 & 100 & 100 & 100 & 100 & 100 & 100 & 100 \\
\hline Source
\end{tabular}

Source: based on information presented in David G. Barker, Values and Volunteering, in 2 VOLUNTEERING IN EUROPE 12, 23-24 (1993).

* Weighted average percentages for response distributions from Belgium, Denmark, France, West Germany, Great Britain, Iceland, Northern Ireland, Ireland, Italy, Netherlands, Norway, Portugal, Spain, and Sweden.

The reasons for becoming a volunteer underscore the importance of social networks in the recruitment of volunteers. Gaskin and Smith report that fortyfour percent of all respondents in their multi-country study learned about volunteering through family and friends; twenty-seven percent by being a member of an organization; and thirteen percent through their church, congregation, or some other form of religious affiliation. ${ }^{53}$ In other words, social capital- the sum of connections individuals have to social institutions-serves as a social inclusion mechanism by making people more likely to volunteer. Indeed, Gaskin and Smith found a strong relationship between membership and volunteering: Sixty percent of all volunteers are members of the organizations in which volunteering take place. ${ }^{54}$ By implication, in communities where such social inclusion mechanisms (for example, the family, friendship networks, community groups, and membership organizations) are less strong, volunteering tends to be less frequent and less developed as a social institution.

The willingness to volunteer and the frequency and pattern of volunteering are not constant over time. Over the last few decades, volunteering has undergone significant changes. The exact nature and end product of these changes is not well understood in their full complexity and implications. What seems clear, however, is that volunteering is subject to the greater individualization and secularization in most industrial countries. Both forces lead away from traditional forms of volunteering. Lifetime volunteering becomes less frequent as voluntary activities are short term. Volunteering is perceived less in terms of

53. See id. at 41.

54. See id. at 33 . 
service to others and is more often tied to qualification and self-interest. Volunteers have become more output-oriented: They look for a link between contributions and efforts on the one hand, and their results on the other hand. As a consequence, volunteers are more interested in shorter-term assignments with tangible payoffs. ${ }^{55}$

Following Barker's framework, we can identify three motivational factors why people volunteer: altruistic, instrumental, and obligatory. ${ }^{56} \mathrm{He}$ suggests a close connection between the rise of instrumental motives and change in volunteering toward greater output orientation. Altruistic motives include notions of a sense of solidarity for the poor, compassion for those in need, identifying with suffering people, and giving hope and dignity to the disadvantaged. Instrumental motives are defined as a desire to gain new experience and new skills, to do something worthwhile in one's spare time, to meet people, and personal satisfaction. Finally, obligation motives include moral and religious duty, contributing to the local community, repaying debt, and a political duty to bring about change. ${ }^{57}$

These motivations rarely occur in isolation. In reality, we normally find different combinations among them. The factor that bound these motivations in the past was frequently religion or, more specifically, religiosity. In fact, many studies suggest that the degree of religiosity is one of the most important factors explaining variations in volunteering both within countries and crossnationally. ${ }^{58}$ It is also the factor that seems to be declining in its importance, particularly in Europe, Australia, and other parts of the developed world with pronounced secularization trends. In these countries, instrumental orientations seem to have increased since the 1980s, while religious values and selfless motivations appear to have lost ground. ${ }^{59}$ In particular, younger cohorts reveal more instrumental and less religious-moralistic attitudes toward volunteering compared to those fifty-five and older. ${ }^{60}$ Volunteering, it seems, is finding new motivational bases, perhaps signaling a continuing shift in overall levels and types of volunteering activities over the next decades.

55. See Barker, supra note 50, at 25-28.

56. See id. at 28.

57. See id.

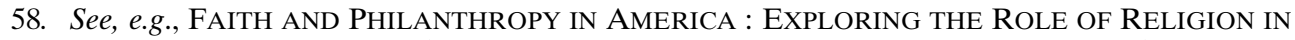
AMERICA's VOLUNTARY SECTOR (Robert Wuthnow \& Virginia A. Hodgkinson eds., 1990); Wojciech Sokolowski, Show Me the Way to the Next Worthy Deed: Toward a Microstructural Theory of Volunteering and Giving, 7(3) VOLUNTAS 259 (1996). In population surveys, religiosity is typically measured by the frequency of religious attendance at a church, synagogue, mosque, or other place of worship. This is a better predictor of volunteering and giving behavior than religious affiliation or denomination, e.g., Catholic, Protestant, Jewish, Islam, etc.

59. See Ronald Inglehart, MOdernization AND POSTMODERnization: Cultural, ECONOMIC, AND POLITICAL CHANGE IN 43 COUNTRIES 72-73 (1997).

60. See Barker, supra note 50, at 25-28. 
IV

\section{CROSS-NATIONAL PATTERNS}

How does volunteering vary across countries, and what is the contribution of volunteers to the size of the nonprofit sector overall? ${ }^{61}$ As part of the Johns Hopkins Comparative Nonprofit Sector Project, we collected basic information on volunteering in more than twenty countries worldwide. ${ }^{62}$ Table 3 shows the relative size of the nonprofit sector for each country included in the study, grouped by geographic regions. We first considered the size of the nonprofit sector without volunteers, that is, looking at paid employment only. Perhaps the most surprising outcome of that comparison is that the United States, commonly thought to have the largest nonprofit sector, ranks only fifth on both the employment and the relevant expenditure measures, behind the Netherlands, Ireland, Belgium, and Israel. ${ }^{63}$

Generally speaking, the nonprofit sector is larger in the more developed countries than in Latin America and Central and Eastern Europe. Table 3 demonstrates that, compared to an average of five percent for all the countries, nonprofit organizations account for close to seven percent of the nonagricultural labor force in Western Europe and in the other developed countries examined in the study. The developing and transition countries were below the five percent means with $2.1 \%$ in Latin America and $1.3 \%$ in Central and Eastern Europe. The scale of the nonprofit sector may relate to the availability of resources, including volunteers, and the capacity of societies to mobilize around social or economic needs.

61. Most studies assume that volunteering takes places in nonprofit or voluntary organizations, and neglect volunteering for public organizations and business. For example, Gaskin and Smith report that in the countries they studied, one in ten volunteers volunteered with state or public organizations. The share of public sector volunteers was highest in Slovakia (23\%), Belgium (20\%) and Germany (14\%), whereas in other countries like Ireland or Sweden, the percentage was very low. See GASKIN \& SMITH, supra note 44 , at 33 .

62. See Lester Salamon et Al., Global Civil Society: Dimensions of the Nonprofit SECTOR 8-29 (1999).

63. See id. at 14 . 
TABLE 3

RELATIVE SIZE OF NONPROFIT SECTOR; WITH AND WITHOUT VOLUNTEERING, BY COUNTRY, 1995-7

\begin{tabular}{|c|c|c|c|c|c|}
\hline \multirow[b]{2}{*}{ Region } & \multirow[b]{2}{*}{ Country } & \multicolumn{4}{|c|}{ Size Indicators } \\
\hline & & $\begin{array}{c}\text { Total Paid } \\
\text { Nonprofit } \\
\text { Employment }\end{array}$ & $\begin{array}{c}\text { Population } \\
\text { Voluneerting }\end{array}$ & $\begin{array}{c}\text { FTE } \\
\text { Volunteers } \\
\text { in } 1,000\end{array}$ & $\begin{array}{c}\text { Total Paid } \\
\text { and Unpaid } \\
\text { Employmment }\end{array}$ \\
\hline \multirow{10}{*}{$\begin{array}{l}\text { European } \\
\text { Union }\end{array}$} & Austria & $4.5 \%$ & $\mathrm{n} / \mathrm{a}$ & 41 & $5.7 \%$ \\
\hline & Belgium & $10.5 \%$ & $30 \%$ & 99 & $13.0 \%$ \\
\hline & Finland & $3.0 \%$ & $33 \%$ & 75 & $6.3 \%$ \\
\hline & France & $4.9 \%$ & $23 \%$ & 1,022 & $9.6 \%$ \\
\hline & Germany & $4.9 \%$ & $26 \%$ & 979 & $8.0 \%$ \\
\hline & Ireland & $11.5 \%$ & $20 \%$ & 32 & $14.2 \%$ \\
\hline & Netherlands & $12.5 \%$ & $46 \%$ & 678 & $18.7 \%$ \\
\hline & Sweden & $2.5 \%$ & $51 \%$ & 229 & $8.3 \%$ \\
\hline & Spain & $4.5 \%$ & $12 \%$ & 254 & $6.8 \%$ \\
\hline & $\mathrm{UK}$ & $6.2 \%$ & $48 \%$ & 1,120 & $10.5 \%$ \\
\hline \multicolumn{2}{|c|}{ European Union Average } & $6.9 \%$ & $32.1 \%$ & 452.9 & $10.3 \%$ \\
\hline \multirow{4}{*}{$\begin{array}{l}\text { Other } \\
\text { Developed } \\
\text { Countries }\end{array}$} & Australia & $7.2 \%$ & $19 \%$ & 177 & $10.1 \%$ \\
\hline & Israel & $9.2 \%$ & $12 \%$ & 32 & $11.0 \%$ \\
\hline & Japan & $3.5 \%$ & very low & 695 & $4.6 \%$ \\
\hline & US & $7.8 \%$ & $49 \%$ & 4,995 & $11.9 \%$ \\
\hline \multicolumn{2}{|c|}{ Other Developed Country Average } & $6.9 \%$ & $26.7 \%$ & 1474.8 & $9.4 \%$ \\
\hline \multirow{4}{*}{$\begin{array}{l}\text { Central } \\
\text { and } \\
\text { Eastern } \\
\text { Europe }\end{array}$} & Czech Rep. & $1.7 \%$ & $\mathrm{n} / \mathrm{a}$ & 94 & $2.7 \%$ \\
\hline & Hungary & $1.3 \%$ & $7 \%$ & 10 & $1.6 \%$ \\
\hline & Romania & $0.6 \%$ & $34 \%$ & 91 & $1.3 \%$ \\
\hline & Slovakia & $0.9 \%$ & $\mathrm{n} / \mathrm{a}$ & 7 & $1.2 \%$ \\
\hline \multicolumn{2}{|c|}{ Central and Eastern Europe Average } & $1.1 \%$ & $20.5 \%$ & 50.5 & $1.7 \%$ \\
\hline \multirow{5}{*}{$\begin{array}{l}\text { Latin } \\
\text { America }\end{array}$} & Argentina & $3.7 \%$ & $20 \%$ & 64 & $6.0 \%$ \\
\hline & Brazil & $2.3 \%$ & $12 \%$ & 139 & $2.5 \%$ \\
\hline & Colombia & $2.4 \%$ & $48 \%$ & 111 & $3.1 \%$ \\
\hline & Mexico & $0.4 \%$ & $\mathrm{n} / \mathrm{a}$ & 47 & $0.7 \%$ \\
\hline & Peru & $2.4 \%$ & $31 \%$ & 26 & $2.9 \%$ \\
\hline \multicolumn{2}{|c|}{ Latin American Average } & $2.2 \%$ & $27.8 \%$ & 77.4 & $\mathbf{3 . 0} \%$ \\
\hline \multicolumn{2}{|c|}{ Grand Average } & $4.8 \%$ & $26.8 \%$ & 193.6 & $6.9 \%$ \\
\hline
\end{tabular}

Source: Employment data, see Lester SALAmon, Helmut K. ANHEIER ET AL., GlobAl Civil SOCIETY: DIMENSIONS OF THE NONPROFIT SECTOR (1999).

Wages + imputed value of voluntary labor, imputed value of volunatry labor also added to GDP. 
$\underline{\text { Source for Volunteering Data }}$

\section{European Union}

Austria Christoph Badelt et al, "Quantitative Dimesnionen des Nonprofit-Sektors in Oesterreich”, Vienna: University of Economic, Abteilung f. Sozialpolitik, 1997.

Belgium J. Defourny et al. 1997 "La demographie et l'emploi remunere des ABL en Belgique.". Universite de Liege: Centre d'economie sociale.

Finland V. Hellander et al. 1999. "Finland" in L.M. Salamon and H.K. Anheier. Global Civil Society: Dimensions of the Nonprofit Sector. Baltimore: Johns Hopkins University Institute for Policy Studies.

France $\quad$ E. Archambault, French Giving and Volunteerting Survey, 1995, Paris: Laboratoire d'economie sociale, Universite de Paris I, Sorbonne.

Germany E. Priller, A. Zimmer and H.K. Anheier, 1996. German Giving and Volunteering Survey, Berlin: Wissenschaftszentrum.

Ireland H. Ruddle and R. Mulvihill, 1994 "Reaching Out: Charitable giving and volunteering in the Republic of Ireland," Dublin: National College of Ireland: Policy Research Centre.

Netherlands A. Burger et al. 1999. "The Netherlands" in L.M. Salamon and H.K. Anheier. Global Civil Society: Dimensions of the Nonprofit Sector. Baltimore: Johns Hopkins University Institute for Policy Studies.

Spain J.I. Ruiz Olabuenaga et al. 1999. "Spain" in L.M. Salamon and H.K. Anheier. Global Civil Society: Dimensions of the Nonprofit Sector. Baltimore: Johns Hopkins University Institute for Policy Studies.

UK J.D. Smith. "The 1997 National Survey of Volunteering”. London: Institute for Volunteering Research, 1998.

\section{Other Developed Countries}

Australia Australian Bureau of National Statistics, 1995 Survey on Voluntary Work. Canberra.

Israel

B. Gidron et al. 1999. "Israel" in L.M. Salamon and H.K. Anheier. Global Civil Society: Dimensions of the Nonprofit Sector. Baltimore: Johns Hopkins University Institute for Policy Studies.

Japan N. Yamauchi et al. 1999. "Japan" in L.M. Salamon and H.K. Anheier. Global Civil Society: Dimensions of the Nonprofit Sector. Baltimore: Johns Hopkins University Institute for Policy Studies.

US Independent Sector, 1996 Giving and Volunteering Survey. Washington DC.

\section{Central and Eastern Europe}

Czech Rep. $\quad$ P. Fric 1999. "Czech Republic" in L.M. Salamon and H.K. Anheier. Global Civil Society: Dimensions of the Nonprofit Sector. Baltimore: Johns Hopkins University Institute for Policy Studies.

Hungary I. Sebesteny et al. 1999. "Hungary" in L.M. Salamon and H.K. Anheier. Global Civil Society: Dimensions of the Nonprofit Sector. Baltimore: Johns Hopkins University Institute for Policy Studies.

Romania D. Saulean et al. 1999. "Romania" in L.M. Salamon and H.K. Anheier. Global Civil Society: Dimensions of the Nonprofit Sector. Baltimore: Johns Hopkins University Institute for Policy Studies.

Slovakia H. Wolekovaet al. 1999. "Slovakia" in L.M. Salamon and H.K. Anheier. Global Civil Society: Dimensions of the Nonprofit Sector. Baltimore: Johns Hopkins University Institute for Policy Studies. 


\begin{tabular}{ll} 
Argentina & \multicolumn{2}{c}{ Latin America } \\
& M. Roitter et al. 1999. "Argentina" in L.M. Salamon and H.K. Anheier. Global Civil \\
& Society: Dimensions of the Nonprofit Sector. Baltimore: Johns Hopkins University \\
Institute for Policy Studies. \\
Brazil & L. Landim et al. 1999. "Brazil" in L.M. Salamon and H.K. Anheier. Global Civil \\
& Society: Dimensions of the Nonprofit Sector. Baltimore: Johns Hopkins University \\
& Institute for Policy Studies. \\
Colombia & R. Villar et al. 1999. "Columbia" in L.M. Salamon and H.K. Anheier. Global Civil \\
& Society: Dimensions of the Nonprofit Sector. Baltimore: Johns Hopkins University \\
& Institute for Policy Studies. \\
Mexico & G. Verduzco et al. 1999. "Mexico" in L.M. Salamon and H.K. Anheier. Global Civil \\
& Society: Dimensions of the Nonprofit Sector. Baltimore: Johns Hopkins University \\
Peru & Institute for Policy Studies. \\
& C. Sanborn et al. 1999. "Peru" in L.M. Salamon and H.K. Anheier. Global Civil \\
& Society: Dimensions of the Nonprofit Sector. Baltimore: Johns Hopkins University \\
& Institute for Policy Studies.
\end{tabular}

In sum, a comparison of the size of the different countries' nonprofit sectors reveals a substantial degree of variability, from about one to thirteen percent of total employment. How does this picture change when we include volunteers? Table 3 shows that the percentage of volunteers in the adult population ranges from a high of nearly fifty percent in the United States to a low of less than ten percent in Hungary, with a mean of $27.7 \%$. For the countries studied, this translates into another 10.4 million full-time equivalent employees, which boosts the total number of full-time equivalent employees of the nonprofit organizations to 29.3 million. ${ }^{64}$ With volunteers included, the nonprofit sector represents, on average, $7.1 \%$ of the total non-agricultural employment in these countries, thirteen percent of the service employment, and forty-three percent of the public sector employment.

In general, adding volunteers widens the range in nonprofit sector size among the countries, from two thirds of one percent in Mexico to nearly nineteen percent in the Netherlands. Thus, volunteer input contributes much more in both relative and absolute terms in the developed countries than it does in the rest of the world. Table 3 confirms this observation, showing the number of volunteers converted to full-time equivalent jobs. The level of volunteering in the developed countries surpasses that of Central and Eastern Europe by a ratio of 5:1, and Latin America by the ratio of 4:1. However, when we consider only the percent of population volunteering, Table 3 reveals that the sharp differences among the countries are less pronounced. The difference between these two measures of volunteering suggests that volunteers in developed coun-

64. The conversion of volunteering into full-time equivalent jobs is accomplished in a number of steps. The data from the various population surveys provide the two key items: the number of volunteers in the sample, and the number of hours volunteered per volunteer. The proportionate share of volunteers is estimated to the whole adult population to yield the total number of volunteers, which, in turn, is multiplied by the average number of hours volunteered. Finally, the total number of hours volunteered is then divided by an average number of full-time equivalent hours per job for each country. 
tries put in more hours on average than their counterparts in the developing world.

$\mathrm{V}$

\section{CROSS-NATIONAL PATTERNS OF VOLUNTEERING}

How can we make sense of the differences in volunteering and the size of the nonprofit sector cross-nationally, as presented in Table 3? Are they more or less random compilations, or do we find systematic patterns in the way different facets and structures relate to one another? If so, what is behind these patterns, and what social, economic, or political forces do they reflect? Based on a modification of Gosta Esping-Andersen's analysis of the welfare state to incorporate the nonprofit sector, ${ }^{65}$ we identified four more or less distinct models of nonprofit development-four "nonprofit regimes." ${ }^{\prime 66}$ Each model is characterized not only by a particular state role, but also by a particular position for the nonprofit sector, including the role of volunteering. Most importantly, each regime type reflects a particular constellation of social forces that help explain cross-national differences in the basic concept and importance of volunteering.

Table 4 differentiates these regimes by considering two key dimensionsfirst, the extent of government social welfare spending, and, second, the economic scale of the nonprofit sector. Table 5, on the other hand, relates the regime types to volunteering. In the liberal model, represented by the United States and the United Kingdom, a lower level of government social welfare spending is associated with a relatively large nonprofit sector. This outcome is most likely where middle-class elements are clearly ascendant, and where opposition either from traditional landed elites or strong working class movements has either never existed or been effectively held at bay. This leads to significant ideological and political hostility to the extension of government social welfare protections and a decided preference for voluntary approaches instead. The upshot is a relatively limited level of government social welfare spending and a sizable nonprofit sector. Volunteering is pronounced, with a strong emphasis on individual public service.

The social democratic model is at the opposite extreme. In this model, exemplified by Sweden or Finland, state-sponsored and state-delivered social welfare protections are extensive, and there is little room left for service-providing nonprofit organizations. ${ }^{67}$ This type of model emerged most likely where working class elements were able to exert effective political power, albeit typically in alliance with other social classes. This is particularly true in much of Scandinavia, where working class political parties were able to demand exten-

(1990).

65. See generally Gosta EsPing-ANDERSEn, The Three Worlds of Welfare CAPITALISM

66. For a more detailed discussion, see Lester M. Salamon \& Helmut K. Anheier, Social Origins of Civil Society: Explaining the Nonprofit Sector Cross-Nationally, 9(3) VOLUNTAS 213 (1998).

67. See Tommy Lundstroem \& Filip Wijckstroem, The Nonprofit Sector in Sweden, in THE JOHNS HOPKINS NONPROFIT SERIES 77-97 (Lester M. Salamon \& Helmut K. Anheier eds., 1997). 
sive social welfare benefits as a matter of right in a context of a weakened, statedominated church and a limited monarchy. Although the result is a limited service-providing nonprofit sector, it is not necessarily a limited nonprofit sector overall. Rather, the nonprofit sector performs a different function in social democratic regimes-an advocacy and personal expression role, rather than actual service-providing. In Sweden, a very substantial network of volunteerbased advocacy, recreational, and hobby organizations exist alongside a highly developed welfare state. ${ }^{68}$ This may help explain our earlier finding that Sweden ranks at the low end of European countries when only paid employment in the nonprofit sector is considered, but it ranks at the high end when we take into account the involvement of volunteers and membership. In this kind of setting, the nonprofit sector may actually come closest to the ideal of a civil society sector functioning to facilitate individual and group expression.

TABLE 4

NONPROFIT SECTOR REGIME TYPES

\begin{tabular}{ccc}
\hline $\begin{array}{l}\text { Government } \\
\text { social spending }\end{array}$ & \multicolumn{2}{c}{ Economic Nonprofit Sector Size } \\
\hline Low & Low & High \\
& Statist & Liberal \\
(Japan) & $\begin{array}{c}\text { (United States and } \\
\text { United Kingdom) }\end{array}$ \\
High & $\begin{array}{c}\text { Social democratic } \\
\text { (Sweden and } \\
\text { Finland) }\end{array}$ & $\begin{array}{c}\text { Corporatist } \\
\text { (Germany and } \\
\text { France) }\end{array}$ \\
\hline
\end{tabular}

TABLE 5

NONPROFIT SECTOR SCALE AND VOLUNTEERING

\begin{tabular}{lcc}
\hline Nonprofit sector type & Size of Paid Labor & Volunteer Input \\
\hline Liberal & High & high \\
Corporatist & High & low \\
Social Democratic & Low & high \\
Statist & Low & low \\
\hline
\end{tabular}

68. See id. at $155-56$. 
Two additional models are characterized by strong states. However, in the corporatist model represented by France and Germany, the state has either been forced or induced to make common cause with nonprofit institutions. In this sense, the nonprofit organizations function as one of the several premodern mechanisms that are deliberately preserved by the state in its efforts to retain the support of key social elites while preempting more radical demands for social welfare protections. This was the pattern, for example, in late nineteenth century Germany, when the state, confronting radical demands from below, forged alliances with the major churches and the landed elites to create a system of state-sponsored welfare provision that, over time, included a substantial role for nonprofit groups, many of them religiously affiliated. ${ }^{69}$ Volunteering in the corporatist state is lower than in both the liberal and the social democratic state, and historically tended to be defined in relation to state provision and administration, for example the German term "honorary office" or Ehrenamt mentioned above. ${ }^{70}$

The statist model is the fourth possible model. In this model, the state retains the upper-hand in a wide range of social policies, but not as the instrument of an organized working class, as in the social democratic regimes. Rather, it exercises power on its own behalf, or on behalf of business and economic elites, but with a fair degree of autonomy sustained by long traditions of deference and a much more pliant religious order. In Japan, for example, limited government social welfare protection does not translate into high levels of nonprofit action, as in the liberal regimes. Rather, both government social welfare protection and nonprofit activity remain highly constrained, as does volunteering.

The developing countries seem, historically at least, close to the statist model of nonprofit development. This conclusion is consistent with several key features of the social circumstances we have identified in these countries-an authoritarian political structure characterized by dominant urban elites holding power in alliance with a colonial administration and, subsequently, its local middle-class elements; a religious apparatus firmly allied with the conservative elites or those holding governmental power; and limited or nonexistent working class power or peasant mobilization. ${ }^{71}$

One of the most salient features of this recent history has been the emergence of newly emboldened educated middle-class elements seeking greater economic and political opportunities. In some countries, political elites have resisted the resulting pressures and sought to dampen the civic activism and nonprofit development to which it has given rise. Elsewhere, however, traditional

69. See Anheier \& Seibel, supra note 31, ch. 3.

70. See Pankoke, supra note 30 , at 162.

71. See Lester M. Salamon \& Helmut K. Anheier, Conclusion: Toward an Understanding of the Nonprofit Sector in the Developing World, in THE NONPROFIT SECTOR IN THE DEVELOPING WORLD 353-63 (Helmut K. Anheier \& Lester M. Salamon eds., 1998). 
elites have sought to encourage civic involvement through grassroots nonprofit institutions and to search for a modus vivendi under which the state and the nonprofit sector can cooperate to promote development. The result is what the social origins approach would characterize as a corporatist model featuring significant expansion of both government and the nonprofit sector to address development needs. ${ }^{72}$ In either case, levels of volunteering remain low.

In summary, according to the social origins theory, we found relative correspondence in nonprofit sector scale and volunteering for countries that fall within the same regime type. Indeed, this result is suggested in Table 5: France $^{73}$ and Germany, ${ }^{74}$ both corporatist regimes are similar in both scale of the nonprofit sector overall and in volunteer input, with twenty-six percent and twenty-three percent of the adult population serving as volunteers. The United Kingdom ${ }^{75}$ and the United States are exemplars of the liberal nonprofit regime. In the United Kingdom and the United States, government social welfare spending is relatively low and the size of the nonprofit sector relatively large. Adult volunteering is much higher than in the corporatist regimes. The United States and the United Kingdom, in turn, are set apart from Sweden, ${ }^{76}$ a social democratic country, where volunteering is rather pronounced, claiming thirtysix percent of the population. Japan exemplifies the statist model, with low levels of government social welfare spending accompanied by a relatively small nonprofit sector. Combined with extensive corporate welfare, the result has been a relatively low level of government social welfare protection without a corresponding growth of independent nonprofit activity. ${ }^{77}$ Volunteering levels are low. The same holds true for the developing countries of Latin America as well as the transition countries of Central and Eastern Europe.

VI

\section{CONCLUSION}

Public discourse in the past suffered frequently from a narrow perception of volunteering. It was seen in isolation of the broader political and economic context in which it takes place. This applies both to the supply and demand of volunteers as well as to the wider implications voluntary efforts have for society. However, there are signs that a more contextual approach toward volunteering is emerging. The greater recognition of value changes, social capital, and social exclusion mechanisms at the local level are indications of this process.

In this context, the social origins theory helps put volunteering in perspective, both in terms of how it relates to the nonprofit sector, and state-society

72. See id. at 369-71.

73. See Edith Archambault, The NonProfit SeCtor In France 199-205 (1997).

74. See Anheier \& Seibel, supra note 31, ch. 3.

75. See Kendall \& Knapp, supra note 28, at 262-66.

76. See Lundstroem \& Wijkstroem, supra note 67, at 155; see also supra Table 1.

77. See Tadashi Yamamoto, The Nonprofit Sector in Japan, in THE JOHnS HopKIns NONPROFIT SERIES 119, 119-27 (Tadashi Yamamoto ed., 1998). 
relations at large. For example, in liberal nonprofit regimes, volunteering plays economically and politically the most important role. It is part of the cultural repertoires of these countries, and typically expected from citizens. In corporatist nonprofit regimes, volunteering is less pronounced and frequently stands in an instrumental and somewhat strained relationship with the state. In social democratic regimes, such strains are typically absent, and the relationship between volunteering and the state is much less instrumental. Volunteering is less linked to service provision, where the state remains dominant, based on a broad political consensus. Volunteering is thus far more a matter of communitybuilding, life style, and recreation. Finally, statist societies have traditionally found no special place for volunteering in the way their societies are structured.

Yet, even in some statist societies, the public recognition and role of volunteers seems to be changing. As mentioned at the beginning of this article, Japan has become active in the proportion of volunteer programs, both domestically as well as internationally. Likewise, Germany is beginning to rebrand volunteering, searching for new terms and mechanisms to engage would be volunteers. $^{78}$ Behind these efforts is the ongoing process to negotiate the public and private involvement of citizens in societies that have become increasingly diverse, mobile, fast changing, and ever more part of a global economy. With these developments, the meaning, roles, and patterns of volunteering are changing, too. Whatever these changes imply in the end, they will probably result in greater importance and recognition of private voluntary activities for the public good.

78. See PeRsPeKTIVEN GESELLSCHAFTLICHEN ZUSAMMENHALTS, supra note 1 , at 77-80. 